\title{
Texas in the Year 1000: What it was Like Then in East Texas
}

Timothy K. Perttula

Heritage Research Center, Stephen F. Austin State University

Follow this and additional works at: https://scholarworks.sfasu.edu/ita

Part of the American Material Culture Commons, Archaeological Anthropology Commons, Environmental Studies Commons, Other American Studies Commons, Other Arts and Humanities Commons, Other History of Art, Architecture, and Archaeology Commons, and the United States History Commons

Tell us how this article helped you.

This Article is brought to you for free and open access by the Center for Regional Heritage Research at SFA ScholarWorks. It has been accepted for inclusion in Index of Texas Archaeology: Open Access Gray Literature from the Lone Star State by an authorized editor of SFA ScholarWorks. For more information, please contact cdsscholarworks@sfasu.edu. 


\section{Texas in the Year 1000: What it was Like Then in East Texas}

Creative Commons License

(c) (i) (8)

This work is licensed under a Creative Commons Attribution-NonCommercial 4.0 International License 


\title{
Texas in the Year 1000: What it was Like Then in East Texas'
}

\author{
Timothy K. Perttula
}

\begin{abstract}
This paper summarizes the native history of the Caddo peoples who lived in East Texas in the Year 1000. Of particular focus are the origins and early developments of the Caddoan tradition, regional diversity, subsistence changes and agricultural intensification, and socio-political dynamics.
\end{abstract}

\section{INTRODUCTION}

The Caddoan peoples in prehistoric and historic times were important political, economic, and social players between Native Americans of the Southeast U.S., the Southern Plains, and the Southwest. In this paper I will summarize the native history of the Caddo peoples who lived in East Texas in the Year 1000. At the turn of the new millenium, there has been considerable interest in what life was like in the last millenium (cf. Lacey and Danziger 2000; U.S. News \& World Report 2000). Of particular focus here are the origins and early developments of the Caddoan cultural tradition, sociopolitical dynamics, and subsistence changes and agricultural intensification. I hope to communicate the broad scope of current and significant archaeological research on the early native history of the Caddo in East Texas.

\section{ENVIRONMENTAL CONTEXT}

In prehistoric times, the Caddoan peoples lived in a distinctive physiographic setting that comprises a diverse set of biotic habitats within the western reaches of the Southeastern U.S., ranging from the westernmost tall-grass prairies and Cross timbers (which expanded and contracted in area with trends in moisture), to the mixed deciduous and pine woodlands of the Ozarks, Ouachita Mountains, and the Gulf Coastal Plain, and then finally to the southern riparian floodplain forests of hardwoods, cypress, and tupelo along the Sabine, Red, Little, and Ouachita rivers.

For the period around A.D. 1000, the environmental conditions and the distribution of biotic habitats closely approximated those of modern times. Tree-ring reconstructions by the Department of Geography at the University of Arkansas indicate major fluctuations in wet and dry conditions during prehistoric times, and these changes presumably affected Caddoan agricultural capabilities and plant food storage reserves. Tree ring data from the Red River valley in northwestern Louisiana show that the Year 1000 was a dry one, although the A.D. $1000-1400$ era was an equitable climatic episode 
when floodplain and upland forests were expanding at the expense of tall-grass prairie, and there were comparable spring rainfall amounts during most of this 400 -year period.

\section{CADDOAN ARCHAEOLOGY}

Best known for its distinctive and beautifully-made engraved ceramic vessels, but also by the massive quantities of exotic prestige goods found at the Spiro site in eastern Oklahoma, the Caddoan archaeological tradition had dispersed but sedentary settlements, a horticultural to agricultural economy, and a complex socio-political structure marked principally by a loosely organized network of mound centers and the differential treatment of the dead by rank, most notably in burial mound shaft tombs accompanied by elaborate grave goods. The evolutionary development of the Caddoan cultural tradition took place relatively independently of the emergence of chiefdom polities in the southeastern U.S. Helen Tanner (1989) sums this up nicely, "The Caddo became the most western of the great chiefdoms that developed in what is now the southeastern United States... Of all the great southeastern chiefdoms, the Caddo was the only one west of the Mississippi River. No other comparable social and political organization existed between the Caddo country and the land of the Anasazi in New Mexico."

\section{Early Developments}

The development of the distinctive Caddoan cultural and archaeological tradition in the Trans-Mississippi South appears to have begun by around A.D. 800-900. The most important processes involved in their appearance and development seem to have included: (a) the rise, elaboration, and maintenance of more complex social and political symbols of authority, ritual, and ceremony focusing on the construction, dismantling, remodeling, and continued use of earthen mounds at important mound centers like Crenshaw, Bowman, Hudnall-Pirtle, and George C. Davis in the southern Caddoan area; (b) the development of elite status positions within Caddoan communities, as well as within regional social and political spheres of Caddoan society; (c) increased sedentism; and (d) the expanding reliance on tropical cultigens in local economic systems, but with an intensification of maize agriculture only after A.D. 1200.

After about A.D. 900 in East Texas, there is clear archaeological evidence for the development of complex and socially ranked societies: well-planned civic-ceremonial centers, elaborate mortuary rituals and ceremonial practices, and evidence for extensive inter-regional trade. The appearance of maize amongst Caddoan peoples seems to have also occurred after ca. A.D. 700/800. Unlike the Mississippi Valley and much of eastern North America, where the appearance of maize between A.D. 700 and 900 is interpreted as the primary addition that nurtured the growth of chiefdom societies, the development of Caddoan agricultural economies--ones based primarily on maize, beans, and squash--is not synchronous with the early growth and elaboration of Caddoan culture. Rather, the significance of the tropical cultigens to Caddoan economies becomes most apparent only 
after ca. A.D. 1200, then intensifying after A.D. 1400, some several hundred years after the initial development of Caddoan culture in the Trans-Mississippi South.

\section{Socio-Political Dynamics}

Considerable recent attention has been focused on the relationship between "maize-centered field agriculture" and the development of complex societies in the Central and Lower Mississippi Valley and the southeastern U.S. This has made evident that there is no causal relationship between either the emergence of such societies, increasingly productive maize varieties, or the development of a uniform pattern of maize-dominated field agriculture. The examination of Caddoan socio-political dynamics, juxtaposed with a changing use of maize and the character of Caddoan agricultural economies, highlights: (a) the non-uniform nature of the relationship between organizational complexity and agriculture in the Caddoan area, and (b) its contrast with other regions of the Southeastern U.S.

Caddoan civic-ceremonial centers around the Year 1000 were marked by the construction of earthen mounds that were used as temples, burial mounds, and ceremonial fire mounds for civic and/or religious functions. It has been suggested that the Caddoan mound-building tradition began as a burial mound tradition along the Red River (perhaps between A.D. 600-900), and that the first construction of flat-topped temple mounds dates several hundred years later. However, flat-topped platform mounds began to be constructed perhaps as early as A.D. 1000 or so in East Texas. The Mound A and B platforms at the George C. Davis site, in deep East Texas, are part of a Caddoan settlement that began in the late 9th or early 10th century and lasted to about A.D. 1290.

The mound centers used by Caddoan groups represented the social and economic focal point of local polities. They were places where sacred rites could be performed, where ritual paraphernalia was stored, and where the important and elite members of Caddoan society met to discuss religious, political, and tribal matters. The largest Caddoan communities and the most significant civic-ceremonial centers (i.e., those with multiple platform mounds and burial mounds centered around large plazas) were distributed along the major streams, namely the Red, Sabine, and Neches rivers in East Texas. The prehistoric archaeological record documents substantial changes in Caddoan socio-political and religious organization over the period from ca. A.D. 800 to European contact. In general, the change is principally from the early development of ranked societies between ca. A.D. 700-900, and in full force in the Year 1000, to a more egalitarian socio-political system 4-6 centuries later where mound centers were no longer constructed and used, long-distance trade efforts diminished, and elaborate mortuary ceremonialism ceased to flourish.

None of the Caddoan communities, towns, or civic-ceremonial centers appear to have been fortified, and there is little, if any, evidence in the prehistoric record in the Year 1000 for warfare between the Caddos and other peoples. This strongly contrasts with the Mississippi Valley and interior Southeast, where palisaded and heavily 
populated towns were common, and centralized polities asserted political and economic authority through warfare.

The civic-ceremonial centers also played special mortuary roles in prehistoric Caddoan polities. The social and political elite were frequently buried in shaft tombs placed in the earthen mounds, and accompanied by many elaborately made grave goods. These grave goods had limited intra-societal distributions, were made frequently on nonlocal materials obtained from great distances (such as copper and conch shell), and usually were obtained through long-distance trade networks. Caddo elite burials in mounds at George C. Davis, Belcher, Haley, Gahagan, Boxed Springs, and Mounds Plantation, for instance, were commonly centrally placed in large and deep grave pits with multiple interments (some being retainer burials), or were placed in (or under) the central area of the mound. The social commoners were buried in family and village cemeteries near the houses they lived in (or in the case of children, buried under the floor of the house). They were probably accompanied by the same rituals and ceremonies as the elites, but without so much 'pomp'.

\section{Settlements and Communities}

In the Year 1000, the Caddoan people lived in sedentary, dispersed communities; there is a preponderance of small sites. These communities consisted of: (1) single homesteads and/or farmsteads with one or two structures and small family cemeteries; (2) small hamlets with a few houses, trash midden deposits, and family cemeteries; and (3) a few larger villages with a patterned arrangement of houses and middens around plazas, and also with cemeteries. Occasionally the villages included small earthen mounds that capped important public structures.

The dispersed communities were associated with civic-ceremonial centers containing earthen mounds and public architecture. The homesteads, farmsteads, and self-sufficient hamlets could be as much as $30 \mathrm{~km}$ from the centers. The most current model of Caddoan settlement is based on the Teran de los Rios 1691 map of the Nasoni village on the Red River, and Soule's 1874 photographs of a Caddoan village (Long Hat's Camp) in western Oklahoma. The Teran map shows that the village was divided into individual compounds containing one to three grass or cane-covered structures, aboveground granaries, outdoor ramadas or arbors, as well as compound cultivated plots, and Soule's photographs capture the relationship between the structures, ancillary facilities, and open plaza-like areas within the compound.

Recent broad-area excavations at Caddoan hamlets or farmsteads show that they were occupied year-round, contained sturdy household structures, smaller wood granaries or ramadas (about 3-5 meters in diameter), as well as extra-mural cooking and working areas near the houses. Midden deposits with household refuse are common in and around the structures and work areas, as are household cemeteries. 


\section{Trade}

The development and maintenance of long-distance trade networks was a notable feature of the prehistoric Caddoan tradition from its very beginnings. Bison hides, salt, raw materials such as copper, galena, stone, and marine shell, and finished objects such as pottery vessels (and their contents), were part of the trading system. Much of the archaeological evidence for the Caddoan long-distance trade and exchange networks occur in contexts dating from ca. A.D. 800 to 1400, with long-distance trade declining after that time.

Certainly the best known examples of Caddoan long-distance exchange are seen in the grave offerings from mound burials from the premier civic-ceremonial centers. Exchanged goods in sites occupied around the Year 1000, the apogee of the long-distance trade network, include a wide variety of ceramic vessels, ceremonial tools, shell gorgets and conchs, shell columella beads, stone pipes, copper masks and repoussé, and large chert bifaces. Evidence of this trade and exchange is clearly indicated by the wide distribution of Caddo ceramic vessels from Mississippian sites in Missouri, Arkansas, Illinois, and Louisiana; Plains Village sites in the Central and Southern Plains, and among hunting-gathering groups in the Texas Panhandle, Caprock Canyonlands, and Central Texas.

\section{Agricultural Economies}

A considerable body of data has been compiled in the last 5-10 years on Caddoan prehistoric plant use. Maize is poorly represented in the Caddoan archaeological record before A.D. 700-900. By A.D. 1200-1300, maize and other domesticates (such as bean) appear to have become an important and primary plant food resource. Oily and starchy seeded plants (sumpweed, sunflower, knotweed, chenopod, maygrass, amaranth, and little barley) were primarily cultivated between ca. A.D. 1100-1400, a period of high diversity in the use of tropical and native plants by Caddoan peoples, but native seed crops do not appear to have been as important in the Caddoan area as they were in the Midwest, and other parts of the eastern U.S.

The introduction of maize into the Caddoan area from the Southwest and Mesoamerica is still poorly understood. The presence or absence of maize in early contexts is affected by factors other than patterns of diet, but also by its early ceremonial significance, its use as a fuel, its preservability, and by techniques of storage. The question of when maize was introduced into the Caddoan area demands further investigation. Its adoption may be a product of both its resource potential and the productivity of existing foraging systems in the region.

By ca. A.D. 1200, an agroecological niche based on maize, beans, and probably squash appears to have been successfully established throughout many regions of the Caddoan area. Natural selection in maize increasingly favored the development of high- 
rowed, small cob varieties because of the long and uniform growing season in East Texas.

\section{Caddoan Faunas}

A high plant diversity is matched by the high diversity in animal resources exploited by Caddoan populations around the Year 1000. While the use of particular species is centered rather consistently around deer, turkey, and aquatic resources, there are significant regional differences. The most diverse Caddoan faunal assemblages occur at sites situated in southeastern floodplain environments (natural levees and point bars) in the Red River Valley. There, the riverine and aquatic habitats were an important source of freshwater aquatic resources gathered (by canoe) in the ponds, sloughs, and backwater channels of active meandering streams near the natural levees frequently used for cultivated fields.

Contemporaneous Caddoan sites outside of the southeastern floodplain habitats are characterized by woodland and forest-edge upland faunal species to the virtual exclusion of aquatic resources. Deer, and later bison in certain settings north of the Red River, were the most abundant game animals utilized by Caddoan populations. Deer frequently accounted for 30 percent or more of the fauna from these areas, and probably as much as 60 to 80 percent of the meat consumed. In southeastern floodplain habitats, on the other hand, fish species such as catfish, gar, and freshwater drum may constitute more than 40 percent of the diverse faunal assemblages in sites.

Caddoan peoples using aquatic resources had the most diverse archaeofaunas, and the lowest relative abundance of large terrestrial species like deer. This type of hunting strategy represents the procurement of species (especially backwater species of fish) that were seasonally abundant energy sources that could be exploited at a relatively low energy levels.

\section{Bioarchaeology}

Infectious disease rates appear to have increased after ca. A.D. $900-1200$ in most Caddoan regions, including East Texas, then remained relatively stable through the 17th century. Trends in the utilization of maize and other domesticates as subsistence staples have been shown to correlate with an increase in the frequencies of infectious diseases.

Isotopic values on human remains dating to around the Year 1000 for stable carbon range are indicative of a diet that is not based on maize. Caddoan period samples dating from ca. A.D. 1100-1300 from two mound centers in southwestern Arkansas and northeastern Texas appear to document a rapid dietary change, with maize becoming a very important food source, comprising perhaps $40-50$ percent of the diet. 
Caddoan bioarchaeological evidence, particularly the rates of caries per person in post A.D. 900-1200 sites, reflects economies where some agriculture is practiced. Rates of caries above 2.0 per person are consistent with diets of carbohydrate or cariogenic-rich foods such as maize and starchy seeds. Caries rates below 2.0 per person, as well as nonmaize stable carbon isotope ratios and high dental abrasion rates indicate no sustained and regional use of tropical and native cultigens in ancestral Caddoan populations dating from ca. 100 B.C. to A.D. 900 . The wealth of new information on caries rates from skeletal populations in the Caddoan area suggests that maize consumption was not uniform from region to region. By A.D. 900 , maize consumption was a conspicuous feature of the diet in each Caddoan region where caries data are available. From that baseline, however, different regions at different times exhibited caries rates most consistent with non-comparable changes in maize utilization.

\section{CONCLUDING REMARKS}

In the Year 1000, Caddoan chiefdoms had developed throughout much, if not all, of East Texas. The Year 1000 was a very good year. These people had powerful religious and political elites, lived in populous communities with important public structures and monuments, and interacted widely with non-Caddoan neighbors to the North, East, and West. At this time, the Caddo were truly masters of their domain, and this was to remain the case for many centuries; indeed, in the late 17th century, the Caddo in East Texas were described by the Spanish as the "Great Kingdom of the Tejas." Circumstances changed rapidly for the Caddo peoples in East Texas after the colonization of the region by the French and Spanish, and within about 150 years of Henri Joutel's visit to the East Texas Caddo, the Caddo peoples had been pushed off their ancestral lands in Texas and forced to flee to Oklahoma or points west along the Brazos River in north central Texas. By 1859, all Caddo peoples resided on a reservation in Western Oklahoma. They left behind a sacred landscape of lost mounds and buried settlements, but these descendants of Caddo chiefdoms have never forgotten the history of their East Texas ancestors.

\section{END NOTE}

- This paper was originally presented at the 2000 Meeting of the Texas State Historical Association, Austin, Texas. 


\section{REFERENCES CITED}

Lacey, R. and D. Danziger

2000 The Year 1000: What Life was like at the turn of the First Millenium. Back Bay Paperbooks, Boston.

Tanner, H. H.

1989 The Land and Water Communication Systems of the Southeastern Indians. In Powhatan's Mantle: Indians in the Colonial Southeast, edited by P. H. Wood, G. A. Waselkov, and M. T. Hatley, pp. 6-20. University of Nebraska Press, Lincoln.

U.S. News \& World Report

2000 The Year 1000: What Life was Like in the Last Millennium. U.S. News \& World Report, Washington, D.C. 